(C) 2013

\author{
Киценко В. П., аспірант
}

Секретаріат Кабінету Міністрів України

(науковий керівник - доктор економічних наук, професор, член-кореспондент НААН України,
Заслужений діяч науки і техніки Украйни В. П. Галушко)

\title{
ІНВЕСТИЦІЙНІ АСПЕКТИ ІННОВАЦІЙНОГО РОЗВИТКУ АПК
}

\section{Рецензент - кандидат економічних наук А. М. Москаленко}

\begin{abstract}
Обтрунтовано необхідність інноваційно-інвестииійного розвитку агропромислового комплексу Украӥни, як одного із провідних секторів економіки. Визначено роль науки, як джерела інновацій. Висвітлено перспективність біологічного вектору розвитку агропромислового виробництва в ицілому та застосування препаратів на основі корисних трунтових мікроорганізмів зокрема. Представлено інновачійні переваги застосування мікробних препаратів як виробничих засобів, значення яких особливо зростає в умовах економічної кризи. На прикладі конкретного інноваційного проекту досліджено ефективність вкладення інвестицій у виробництво продукиії сільськогосподарської мікробіології.
\end{abstract}

Ключові слова: інновачії, інвестииії, мікробні препарати, ринок біопрепаратів, проект, ефективність.

Постановка проблеми. Відповідно до Стратегії економічного і соціального розвитку України (2004-2015 pр.) передбачено утвердження інноваційної моделі розвитку економіки, становлення в Україні принципово нової дієздатної національної системи, яка може функціонувати на ринкових засадах та принципах самовідтворення [5].

Важливим у цьому контексті $є$ визначення пріоритетних напрямів розвитку економіки, до першочергових із яких відносять і виробництво екологічно чистої харчової продукції [4].

У цьому плані одним із найбільш економічно активних секторів економіки, що динамічно розвивається, $\epsilon$ агропромисловий комплекс України. Тут великого значення набуває інноваційно перебудована аграрна наука [3]. В даному сенсі пріоритетним постає розробка і впровадження інноваційних засобів біологізації виробництва, зокрема мікробних препаратів, із відповідним інвестиційним забезпеченням цієї діяльності [6].

Аналіз основних досліджень і публікацій, у яких започатковано розв'язання проблеми. Загальновизнаним $\epsilon$ те, що основою економічного зростання будь-якої країни слугує зокрема активна інноваційно-інвестиційна діяльність на базі використання досягнень науково-технічного прогресу, яка, у свою чергу, забезпечує сприятливі умови для його подальшого розвитку. Як свідчать досягнення XX століття, рівень розвитку науково-технічної сфери - науки, освіти, наукоємних галузей, світових ринків технологій - визначає межі між багатими та бідними державами, створює основу стійкого економічного росту, являється важливим фактором розв'язання соціальних проблем [1, 2]. Саме інноваційні процеси виступають рушійною силою, яка впливає на стратегічний економічний розвиток [3].

Отже лише за умови пріоритетності інноваційного шляху розвитку можна здійснити структурну перебудову української економіки, подолати сировинний вектор іiі розвитку і утвердити Україну як конкурентоспроможну високотехнологічну державу [4].

У цьому плані подальший динамічний розвиток агропромислового комплексу України, як одного із пріоритетних секторів економіки, досягнення стабільного економічного зростання, створення цивілізованих соціально-економічних умов на селі можливі за рахунок розвитку ефективного підприємництва в аграрному секторі, підвищення конкурентоспроможності продукції вітчизняного агропромислового комплексу на внутрішньому та зовнішньому ринках. Розв'язати ці стратегічні завдання можна насамперед шляхом переведення всієї галузі на інноваційну модель розвитку, нарощування обсягів інвестицій та інноваційних самоінвестицій, побудови ринкової інфраструктури, яка б забезпечила функціонування науки разом із підприємництвом в єдиному збалансованому комплексі [3]. До того ж аналіз тенденцій останніх років свідчить про високу та все більш зростаючу інвестиційну привабливість вітчизняного аграрного сектору.

Мета роботи - дослідження інвестиційних аспектів інноваційного розвитку АПК у плані ефективності інновацій у галузі сільськогосподарської мікробіології.

Завдання: визначення тенденцій розвитку ринку біопрепаратів в Україні, оцінка інвестиційної привабливості галузі сільськогоподарсь- 


\section{СТОРІНКА МОЛОДОГО ВЧЕНОГО}

кої мікробіології в плані інновацій, які вона пропонує для АПК, та дослідження ефективності вкладення інвестицій у виробництво препаратів на основі корисних грунтових мікроорганізмів.

Матеріали і методи досліджень. Дослідження інвестиційної привабливості інновацій у галузі сільськогосподарської мікробіології проводилося на підставі оцінки переваг застосування засобів біологізації аграрного виробництва; аналізу сучасних процесів на ринку біопрепаратів у розрізі стану та динаміки попиту і пропозиції, визначення ефективності виробництва мікробних препаратів.

Об’єктами дослідження є мікробні препарати, ринок засобів біологізації для АПК, інвестиційний проект із виробництва біодобрив на основі корисних грунтових мікроорганізмів.

У процесі дослідження використовувалися методи: порівняльного аналізу, економіко-статистичний, розрахунково-конструктивний, прогнозування.

Результати досліджень. Важлива роль в інноваційному розвитку АПК належить біологічному напряму i, зокрема, застосуванню біологічних препаратів, передусім вітчизняного виробництва. На даний час зазначений напрям представлено широким спектром різноманітних засобів. Зокрема науковцями України розроблено низку високоефективних препаратів землеудобрювальної дії.

Діючою основою цих мікробних препаратів $\epsilon$ корисні грунтові мікроорганізми, які виконують роль трофічного посередника між грунтом і рослиною, забезпечуючи засвоєння рослиною елементів живлення із грунту та азоту повітря.

Важливою перевагою даних біопрепаратів у порівнянні 3 мінеральними добривами $є$ те, що невикористані рослиною залишки останніх вимиваються 3 грунту, збільшуючи хімічне навантаження на довкілля, тоді як мікроорганізми позбавлені такого недоліку, а наповнювачі для препаратів є органічною речовиною.

Крім того, результати експериментальних досліджень свідчать про те, що навіть після збору урожаю мікроорганізми продовжують функціонувати, завдяки чому відновлюється біологічний нормоценоз грунтів.

Таким чином, застосування даної продукції приносить також і значний екологічний ефект.

Біологічні препарати мають відносно низьку собівартість, технологічні, нешкідливі для людини та навколишнього середовища.

Особливої актуальності зазначені економічні переваги біопрепаратів набувають у сучасних складних економічних реаліях в Україні й, від- повідно, скрутного фінансового стану багатьох сільськогосподарських товаровиробників. Впровадження інновацій зазвичай потребує значних фінансових ресурсів (переважно капітального характеру), які проблематично відшукати за таких умов. До того ж нестабільність, особливо зовнішнього середовища, якою супроводжуються кризові явища, багатократно підвищує ризикованість інноваційно-інвестиційної діяльності. Окремі практики навіть радять у такій ситуації дотримуватися захисної стратегії, передусім згортання виробництва та скорочення витрат. За таких умов перспективними є такі інновації, які забезпечують значний i швидкий економічний ефект і не потребують значних інвестицій [6].

Саме цим вимогам у найбільшій мірі відповідають біопрепарати як об'єкт інвестування. Зазначене обумовлює досить високу інвестиційну привабливість ринку біопрепаратів в Україні. Обсяги виробництва даної продукції поки що недостатні для задоволення існуючого попиту, навіть за тих обставин, що біопрепарати використовує поки що незначна частина (за деякими розрахунками - не більше 5 \%) вітчизняних сільськогосподарських товаровиробників.

Промислове виробництво біопрепаратів в Україні практично відсутнє. Потреби сільського господарства в біопрепаратах частково задовольняються їх виготовленням в окремих науководослідних установах, проте лабораторні можливості для вирішення даної проблеми надто обмежені. За відсутності вітчизняного промислового виробництва біопрепаратів свого часу активізувався імпорт даної продукції 3 інших країн, зокрема таких як Агат-25 (Росія), Бактофіт (Угорщина), Hi-Stick (Канада, США) тощо.

Останнім часом виробництвом мікробних препаратів почали займатися окремі комерційні структури. Проте низька якість препаратів, виготовлених у неналежних умовах без наукового супроводу розробок, не забезпечує відповідної віддачі й може лише дискредитувати їх реальну ефективність. До того ж основне спрямування переважної частини зазначеної продукції полягає в підвищенні урожайності за рахунок дії біостимуляторів росту рослин та розвитку їх кореневої системи, в той час як мікробні препарати мають більш широкий і глибинний комплексний спектр дії. У цілому ж експерти відзначають наявність досить високого попиту на ринку біопрепаратів в Україні.

Особливо перспективним виглядає різке скорочення імпорту даної продукції, що спостерігається в останні роки. Так, згідно 3 проведеними маркетинговими дослідженнями КК «Бізнес- 


\section{СТОРІНКА МОЛОДОГО ВЧЕНОГО}

Формат», питома вага мікробних/органічних добрив у загальній структурі імпорту біопрепаратів у натуральному виразі зменшилася з 27,6-40,1\% у 2008-2009 рр. до 3,7-6,7 \% у 2010-2011 pр. і до 13,1\% у січні-квітні 2012 р. при загальному скороченні імпорту біопрепаратів. Викладене свідчить про високу та довгострокову вигідність вкладення інвестицій у розвиток даної галузі.

Інноваційна діяльність є одночасно й економічним явищем і процесом. Як економічне явище інноваційна діяльність $€$ формою економічних відносин при створенні та реалізації конкретних новинок. Інноваційна діяльність як процес - це послідовність дій від пошуку нової ідеї до її втілення у конкретний інноваційний проект та отримання прибутку [1].

Одним із прикладів такого проекту є розроблений в Інституті сільськогосподарської мікробіології та агропромислового виробництва НААН інвестиційний проект «Виробництво сучасних біодобрив на основі корисних мікроорганізмів». Суттю проекту є налагодження вітчизняного виробництва на промисловій основі мікробних препаратів, передусім землеудобрювальної дії.

Інвестиційні витрати на реалізацію проекту становлять 13,950 млн грн, у т. ч.: 11,254 млн грн на формування основних фондів, 2,696 млн грн для формування оборотних фондів. Термін окупності інвестицій становить 3 роки 4 місяці від початку виробництва (за найбільш імовірного сценарію реалізації проекту). Термін виконання проекту становить 6 років (2014-2019рр.) із яких рік - на організацію та налагодження виробництва і 5 років - активна стадія реалізації проекту (промисловий випуск препаратів). За найбільш імовірним сценарієм реалізації проекту обсяги виробництва та реалізації продукції планується довести від 234,5 тис. гектарних порцій у перший рік до 459,1 тис. - на п’ятий рік активної фази.

3 урахуванням накопиченого досвіду ціноутворення, платоспроможного попиту, ситуації на ринку та рівня витрат на виробництво прийнято середню ціну мікробних препаратів на рівні 39,55 грн за гектарну порцію (без ПДВ). Залежно від строків реалізації проекту та відповідної динаміки рівня інфляції, цін на ресурсному ринку, цін конкурентів та з урахуванням чутливості й еластичності попиту можливим $є$ уточнення ціни. Даний рівень ціни відповідає середньому рівню на подібну продукцію вітчизняного виробництва. Порівняно $з$ цінами на подібні імпортні товари він $є$ значно нижчим за ефект від застосування біопрепаратів.
Такий підхід до ціноутворення, зокрема низький рівень ціни по відношенню до ефекту, має такий недолік як загроза дискредитації інноваційного продукту. Водночас дотримання саме зазначених принципів ціноутворення обумовлене наступними вагомими чинниками:

- стадія життєвого циклу продукції галузі. Хоча дані товари позиціонують на ринку вже не один рік, але з урахуванням обсягів реалізації, ступеня поширення та сприйняття з боку споживачів iii можна визначити як фазу впровадження - початок фази дифузії.

У зв'язку з новизною, відносною нетрадиційністю і маловідомістю біопрепаратів як засобів виробництва порівняно з традиційними агрохімікатами спостерігається певна обережність споживачів, які раніше не мали з ними справи, недостатній рівень їх психологічної й технологічної готовності.

В окремих випадках внаслідок порушення інструкції із застосування спостерігався негативний результат (склеювання насіння і викликані цим проблеми під час сівби тощо);

- сучасний напружений фінансовий стан багатьох підприємств;

- оскільки бактерії є живими організмами, то вони також певною мірою відчувають на собі вплив природно-кліматичних факторів (у роки зі сприятливими погодними умовами спостерігається підвищення ефекту від застосування біопрепаратів, а в несприятливі роки - певне зменшення);

- практика свідчить про значну чутливість та еластичність попиту до цінових коливань. Так, підвищення ціни понад зазначений рівень призводило до суттєвого падіння попиту;

- даний рівень ціни з урахуванням собівартості продукції забезпечує прийнятний рівень економічної ефективності виробництва.

3 огляду на вищезазначене, найбільш прийнятним варіантом цінової політики $є$ комбінація таких стратегій ціноутворення як проникнення й укорінення на ринку та заволодіння більшою питомою вагою ринку за показниками якості товарів 3 орієнтацією на попит і можливості ринку. Планується впровадження гнучкої цінової політики з використанням системи знижок.

Специфічною особливістю даної продукції, яку необхідно враховувати в процесі розробки маркетингової та цінової політики, $є$ різка сезонність застосування біопрепаратів, що безпосередньо пов'язана зі строками проведення посівних робіт.

Із досвіду діяльності спостерігається два періоди реалізації на рік, які за строками відповідають весняному посіву ярих культур та літньоосінньому посіву озимини. 


\section{СТОРІНКА МОЛОДОГО ВЧЕНОГО}

В останні роки на перший період припадає близько 90 \% річних обсягів продажу, на другий - близько $10 \%$.

Погодні умови конкретного року, що позначаються на тривалості та строках проведення посівної кампанії, відповідним чином впливають і на сезонність реалізації.

Аналіз динаміки попиту свідчить про те, що основним фактором сезонності реалізації $\epsilon$ сезонність проведення сільськогосподарських робіт, а не технологічні особливості біопрепаратів (деякі із них мають рідку форму й непридатні до тривалого зберігання, але щодо препаратів, які мають суху форму і придатні до зберігання, теж спостерігається сезонність реалізаціі).

3 урахуванням викладеного та 3 метою пом'якшення сезонності реалізації й забезпечення більш рівномірного надходження грошових коштів за періодами року передбачено систему знижок і надбавок до середньої базової ціни. Крім того, налагодження роботи розпилювальної сушарки (що заплановано у проекті) дасть змогу виготовляти препарати тривалого терміну зберігання саме в періоди міжсезоння.

Основним каналом реалізації (понад $70 \%$ продукції) у найближчій перспективі буде дилерська мережа, яка значною мірою вже сформована в процесі маркетингової діяльності Інституту і в географічному плані охоплює значну територію України з підвищеною активністю у віддалених від м. Чернігова регіонах із вищим рівнем розвитку сільськогосподарського виробництва.

Можливими і перспективними є також поставки на зовнішній ринок, інтерес з боку якого до даного виду продукції останнім часом помітно підвищується. Основні виробничі та економічні показники виробництва біопрепаратів за час активної фази реалізації проекту (за найбільш імовірного сценарію його реалізації) наведено в таблиці 1.

Із аналізу даних таблиці 2 слідує, що розглядуваний проект має високу виробничу ефективність: рентабельність виробництва підвищується iз 33,0 \% у перший рік активної фази до 78,6 \% на п'ятий рік, у середньому складаючи $61,4 \%$. До того ж собівартість одиниці продукції щороку знижується.

Не менш привабливими $є$ також показники інвестиційної ефективності проекту (табл. 2).

\section{1. Динаміка основних виробничих та економічних показників із початку виробництва}

\begin{tabular}{|l|c|c|c|c|c|c|}
\hline Показники & 2015 p. & 2016 p. & 2017 р. & 2018 p. & 2019 p. & Разом \\
\hline $\begin{array}{l}\text { Обсяги виробництва та реалізації } \\
\text { продукції, тис. га п. }\end{array}$ & 234,5 & 286,0 & 337,5 & 411,6 & 459,1 & 1728,2 \\
\hline $\begin{array}{l}\text { Виручка від реалізації продукції } \\
\text { (без ПДВ), тис. грн }\end{array}$ & 7589,2 & 10060,3 & 12388,2 & 15870,2 & 18457,1 & 64365,0 \\
\hline Ціна 1 га п. без ПДВ, грн & 32,36 & 35,18 & 36,71 & 38,56 & 40,20 & 37,24 \\
\hline Усього витрат, тис. грн & 5706,2 & 6765,9 & 7814,1 & 9251,0 & 10334,8 & 39872,0 \\
\hline у т. ч.: - матеріали, тис. грн & 698,9 & 1002,6 & 1433,2 & 2099,6 & 2579,5 & 7813,8 \\
\hline $\begin{array}{c}\text { - оплата праці з нарахуван- } \\
\text { нями, тис. грн }\end{array}$ & 1526,3 & 1980,1 & 2361,2 & 2852,0 & 3166,1 & 11885,7 \\
\hline Собівартість одиниці продукції, грн & 24,33 & 23,66 & 23,15 & 22,48 & 22,51 & 23,07 \\
\hline Валовий прибуток, тис. грн & 1883,0 & 3294,4 & 4574,1 & 6619,2 & 8122,3 & 24493,0 \\
\hline Рентабельність виробництва, \% & 33,0 & 48,7 & 58,5 & 71,6 & 78,6 & 61,4 \\
\hline
\end{tabular}

\section{2. Основні показники інвестиційної ефективності проекту}

\begin{tabular}{|l|c|c|c|}
\hline \multirow{2}{*}{\multicolumn{2}{|c|}{ Показник }} & \multicolumn{3}{|c|}{ Сценарії реалізації проекту } \\
\cline { 2 - 4 } & песимістичний & найбільш імовірний & оптимістичний \\
\hline Термін окупності з початку вироб- & 3 роки & 3 роки & 2 роки \\
ництва & 5 місяців & 4 місяці & 8 місяців \\
\hline Середня норма рентабельності, \% & 31,4 & 32,4 & 38,4 \\
\hline Чистий приведений ефект, тис. грн & 545,3 & 983,0 & 3695,1 \\
\hline Індекс рентабельності & 1,04 & 1,08 & 1,30 \\
\hline Внутрішня норма рентабельності, \% & 24,0 & 25,5 & 35,3 \\
\hline Кількість створених робочих місць & 34 & 34 & 34 \\
\hline
\end{tabular}




\section{СТОРІНКА МОЛОДОГО ВЧЕНОГО}

Так, за всіх прогнозованих сценаріїв реалізації проекту він забезпечує високу ефективність вкладених інвестицій.

Висновок. На підставі викладеного можна дійти висновку, що галузь сільськогосподарської мікробіології має високу інвестиційну привабли-

\section{БІБЛІОГРАФІЯ}

1. Акофф $P$. Планирование в больших экономических системах / Р. Акофф. - М. : Советское радио, 1972. - 223 с.

2. Актуальні питання методології та практики науково-технічної політики / За ред. Б. А. Малицького. - К. : УкрIHTEI, 2001. - 201 с.

3. Володін C. А. Теоретико-методологічні та організаційні засади інноваційного провайдингу на наукоємному аграрному ринку / С. А. Володін. К. : ЗАТ «Нічлава», 2007. - 384 с.

4. Москаленко А. М. Посилення ролі держави на шляху до інноваційного розвитку України / А. М. Москаленко, Ю. М. Халеп // Збірник тез Всеукраїнської науково-практичної конференції «Формування стратегії розвитку України як передумова сталого зростання». - Чернігів : ЧФ вість у плані інновацій, які вона пропонує для АПК.

Розроблені в Україні інвестиційні проекти не тільки сприятимуть вирішенню актуальної народногосподарської задачі, але й забезпечать високу ефективність вкладень.

КСУ, 2010. - С. 79-80.

5. Стратегія економічного і соціального розвитку України (2004-2015 рр.) Шляхом Свропейської інтеграції / А. С. Гальчинський, В. М. Геєць та ін. / Нац. ін-т стратег. дослідж., Ін-т екон. прогнозування НАН України, М-во економіки та з питань Європ. інтегр. України. - К.: ІВЦ Держкомстату України, 2004. - 416 с.

6. Халеп Ю. М. Особливості інноваційних процесів в умовах економічної кризи / Ю. М. Халеп, А. М. Москаленко // Збірник тез Всеукраїнської науково-практичної конференції «Формування антикризового механізму соціально-економічного розвитку України». - Чернігів : ЧФ КСУ, 2009. - С. 73-76. 